\title{
EVALUASI PENERAPAN PERENCANAAN PAJAK ATAS PAJAK PENGHASILAN (PPH PASAL 25) PADA PT. BANK SULUTGO
}

\author{
Steven Karuniawan ${ }^{1}$, Jenny Morasa ${ }^{2}$, Stanley Kho Walandouw ${ }^{3}$ \\ ${ }^{1,2,3}$ Jurusan Akuntansi, Fakultas Ekonomi dan Bisnis, Universitas Sam Ratulangi, Jl. Kampus Unsrat Bahu, \\ Manado, 95115, Indonesia \\ E-mail : karuniawansteven@gmail.com
}

\begin{abstract}
Tax planning is one way to optimize profits because the tax is a burden / expense that reduces revenue so that efforts to reduce tax payments are often done companies. PT.Bank SulutGo in tax payments to the government has a role as one of the largest contributor to tax revenue for North Sulawesi Because PT.Bank SulutGo is a Regional Development Bank which Labanya increase every year. The purpose of this research is to know the application of tax planning to income tax Article 25 at PT. Bank SulutGo. The object of this research is Income Statement of PT. Bank SulutGo for the year ended 31 December 2016. The methodology used in this research is qualitative research. Writing method used is descriptive method that is field study by doing observation, interview, and documentation and library study. The result of evaluation of this research is expected to give information and input for company in doing tax planning as effort of tax payment efficiency to achieve maximum profit. But still in accordance with the provisions of the applicable taxation The conclusions of this study indicate that tax planning applied by PT. Bank SulutGo is in compliance with applicable tax laws.
\end{abstract}

Keywords:Tax Planning and Income Tax Article 25

\section{PENDAHULUAN}

Sebagai negara berkembang yang berada dalam masa pembangunan, Indonesia membutuhkan dana yang tidak sedikit untuk menyelenggarakan pemerintahan dan membiayai pembangunan guna menciptakan masyarakat yang adil dan makmur. Sumber dana yang diperlukan untuk menyelenggarakan pemerintahan dan membiayai pembangunan tersebut sebagian berasal dari sektor pajak.

Dalam usaha untuk memaksimalkan penerimaan dari sektor pajak, pemerintah sering melakukan perbaikan, penyesuaian, dan perubahan terhadap undang-undang perpajakan yang berlaku saat ini terutama pajak penghasilan yang telah mengalami tiga kali perubahan. Penghasilan adalah salah satu objek pajak. Pajak penghasilan dikenakan terhadap subjek pajak atas penghasilan yang diterima atau diperolehnya dalam tahun pajak. Pajak penghasilan tergolong pajak subjektif, yaitu pajak yang mempertimbangkan keadaan pribadi wajib pajak sebagai faktor utama dalam pengenaan pajak.

Pajak adalah iuran rakyat kepada kas Negara berdasarkan undang-undang, sebagai perwujudan pengabdian dan peran serta rakyat untuk membiayai negara dan pembangunan nasional (Prasetyono 2011:13) Pengertian Pajak Penghasilan Pasal 25, menurut Undangundang pajak penghasilan No. 36 Tahun 2008, PPh pasal 25 merupakan besarnya angsuran pajak yang harus dibayar sendiri oleh wajab Pajak untuk bulan-bulan sebelum batas waktu penyampaian Surta Pemberitahuan Tahunan Pajak Penghasilan sama dengan besarnya angsuran pajak untuk bulan terakhir tahun pajak yang lalu (Suprianto 2011:49) Adapun perhitungan untuk mengetahui jumlah pajak badan yang terutang diatur dalam ketentuan Pajak Penghasilan Pasal 25. 
Pada masa sekarang ini pendapatan Negara khususnya dari PPh pasal 25 sangat berperan penting untuk penyelenggaraan pembangunan dalam rangka mewujudkan kehidupan masyarakat yang sejahtera adil dan makmur. PT.Bank SulutGo adalah usaha yang bergerak dibidang keuangan atau jasa keuangan. Produk utama yang biasa dilayani berupa simpaan giro, tabungan maupun deposito. PT.Bank SulutGo juga sebagai tempat untuk simpan pinjam atau kredit bagi warga masyarakat yang membutuhkan dana pinjaman. PT.Bank SulutGo dalam pembayaran pajak ke pemerintah memiliki peran sebagai salah satu penyumbang terbesar penerimaan pajak bagi Sulawesi Utara Karena PT.Bank SulutGo adalah Bank Pembangunan Daerah yang Labanya setiap tahun mengalami peningkatan.

Berdasarkan uraian tersebut, untuk memperoleh gambaran yang lebih jelas tentang perpajakan, khususnya mengenai bagaimana suatu perusahaan menentukan besarnya Pajak Penghasilan dalam hal ini PPh Pasal 25 yang harus dilaporkan dan disetorkan kepada pemerintah dan apakah perhitungan dan pelaporan Pajak Penghasilan telah sesuai dengan ketentuan yang berlaku, maka penulis mengambil judul analisis perhitungan dan pelaporan Pajak Penghasilan Pasal 25 Oleh karena itu, diperlukan manajemen pajak yang bertujuan menekan pajak serendah mungkin dan menunda selambat mungkin pembayaran pajak untuk memperoleh laba likuiditas yang diharapkan.Berdasarkan uraian di atas, maka peneliti tertarik untuk melakukan penelitian yang berjudul :"Evaluasi Penerapan Perencanaan Pajak Atas Pajak Penghasilan PPh Pasal 25 Pada PT. Bank SulutGo"

\section{TINJAUAN PUSTAKA}

\subsection{Konsep Akuntansi dan Perpajakan}

American Accounting Association yang dikutip oleh Soemarso S.R (2011 :3) Akuntansi sebagai suatu proses mengidentifikasikan, mengukur, dan melaporkan informasi ekonomi, untuk memungkinkan adanya penilaian dan keputusan yang jelas dan tegas bagi mereka yang menggunakan informasi tersebut. Lili M. Sadeli (2012 :Akuntansi adalah proses mengidentifikasikan, mengukur dan melaporkan informasi ekonomi untuk membuat pertimbangan dan mengambil keputusan yang tepat bagi pemakai informasi tersebut.

Suprianto (2011 :49) Soemitro dalam Widyaningsih (2011 :2) Mengemukakan definisi pajak adalah peralihan kekayaan dari pihak rakyat kepada Kas Negara untuk membiayai pengeluaran rutin dan surplusnya digunakan untuk public saving yang merupakan sumber utama membiayai public investment.Akuntansi perpajakan adalah sebagai bagian dari akuntansi yang menekankan konsekuensi perpajakan terhadap transaksi atau kegiatan perusahaan. Akuntansi perpajakan secara khusus menyajikan laporan keuangan dan informasi lain kepada administrasi pajak.

\subsection{Pajak Penghasilan}

Waluyo (2008:87) mengemukakan Pajak Penghasilan adalah pajak yang dibebankan pada penghasilan perorangan, perusahaan atau badan hukum lainnya.Pajak penghasilan bisa diberlakukan progresif, proporsional atau regresif. UU No 7 tahun 1983 tentang $\mathrm{PPh}$ sebagaimana yang telah beberapa kali diubah terakhir dengan UU No 36 Tahun 2008, (selanjutnya disebut dengan UU PPh).

Undang-undang Pajak Penghasilan ( $\mathrm{PPh}$ ) mengatur pengenaan Pajak Penghasilan terhadap subjek pajak berkenaan dengan penghasilan yang diterima atau diperolehnya dalam tahun pajak.Subjek pajak tersebut dikenai pajak apabila menerima atau memperoleh penghasilan. Subjek pajak yang menerima atau memperoleh penghasilan dalam UndangUndang PPh disebut Wajib Pajak. Wajib Pajak dikenai pajak atas penghasilan yang diterima atau diperolehnya selama satu tahun pajak atau dapat pula dikenai pajak untuk penghasilan 
dalam bagian tahun pajak apabila kewajiban pajak subjektifnya dimulai atau berakhir dalam tahun pajak.

\subsection{Pajak Penghasilan Final}

Berdasarkan UU PPh pasal 4 ayat (2) No. 36 Tahun 2008, Pajak Penghasilan yang bersifat final terdiri dari sebagai berikut.

1. Penghasilan berupa bunga deposito dan tabungan lainnya, bunga obligasi dan surat utang negara, dan bunga simpanan yang dibayarkan oleh koperasi kepada anggota kopersi orang pribadi.

2. Penghasilan berupa hadiah undian.

3. Penghasilan dari transaksi saham dan sekuritas lainnya, transaksi derivative yang diperdagangkan di bursa, dan transaksi penjualan saham atau pengalihan penyertaan modal pada perusahaan pasangannya yang diterima oleh perusahaan modal ventura.

4. Penghasilan dari transaksi pengalihan harta berupa tanah dan/atau bangunan, usaha jasa kontruksi, usaha real estate, dan persewaan tanah dan/atau bangunan.

5. Penghasilan tertentu lainnya (penghasilan dari pengungkapan ketidakbenaran, penghentian penyidikan tindak pidana, dan lain-lain). pajak-pajak tersebut selanjutnya dinamakan UU PPh pasal 4 ayat (2).

\subsection{Tarif Pajak Penghasilan}

Tabel 2.2 Wajib Pajak Badan dalam negeri dan bentuk usaha tetap

\begin{tabular}{|c|c|}
\hline Tahun Pajak & Tariff Pakak \\
\hline 2009 & $28 \%$ \\
\hline 2010 dan selanjutnya & $25 \%$ \\
\hline $\begin{array}{c}\text { PT yang 40\% sahamnya diperdagangkan } \\
\text { di bursa efek }\end{array}$ & $5 \%$ lebih rendah dari seharusnya \\
\hline $\begin{array}{c}\text { Pendapatan bruto sampai dengan Rp } \\
50.000 .000\end{array}$ & Pengurangan 50\% dari yang seharusnya \\
\hline
\end{tabular}

Sumber: Undang-undang Nomor 36 Tahun 2008

Memperoleh tarif sebesar 5\% (lima persen) lebih rendah dari pada tarif sebagaimana di maksud pada ayat (1) huruf b dan ayat (2) huruf a yang di atur dengan atau berdasarkan Peraturan Pemerintah. Tarif yang dikenakan atas penghasilan berupa dividen yang dibagikan kepada Wajib Pajak orang pribadi dalam negeri adalah paling tinggi sebesar $10 \%$ (sepuluh persen) dan bersifat final. Wajib Pajak dalam negeri dengan peredaran brutonya dalam 1 (satu) tahun sampai dengan 50 miliar mendapat fasilitas berupa pengurangan tarif sebesar $50 \%$ dari tarif sebagaimana dimaksud dalam pasal 17 ayat (1) huruf b dan ayat (2a) yang dikenakan atas Penghasilan Kena Pajak dari bagian peredaran bruto sampai dengan4,8 miliar (Pasal 31 E UU PPh).

\section{Pengertian Pajak Penghasilan PPh Pasal 25}

Muljono (2009) Menyatakan bahwa pajak Penghasilan (disingkat PPh) dikenakan terhadap Wajib Pajak dalam satu periode tertentu yang dinamakan tahun pajak. Berdasarkan hal ini, maka perhitungan dan penghitungan PPh dilakukan setahun sekali yang dituangkan dalam SPT Tahunan. Karena penghitungan PPh dilakukan setahun sekali, maka penghitungan ini harus dilakukan setelah satu tahun tersebut berakhir agar semua data penghasilan dalam satu tahun sudah diketahui. Untuk perusahaan, tentu saja data penghasilan ini harus menunggu laporan keuangan selesai dibuat. Cara seperti itu tentu saja jumlah PPh terutang yang wajib dibayar baru dapat diketahui ketika suatu tahun pajak telah berakhir. Agar 
pembayaran pajak tidak dilakukan sekaligus yang tentunya akan memberatkan, maka dibuatlah mekanisme pembayaran pajak di muka atau pembayaran cicilan setiap bulan. Pembayaran angsuran atau cicilan ini dinamakan Pajak Penghasilan Pasal 25.

\section{Cara Menghitung PPh Pasal 25}

Besarnya angsuran PPh Pasal 25 harus dihitung sesuai dengan ketentuan. Pada umumnya, cara menghitung PPh Pasal 25 didasarkan kepada data SPT Tahunan tahun sebelumnya. Artinya, kita mengasumsikan bahwa penghasilan tahun ini sama dengan penghasilan tahun sebelumnya. Tentu saja nanti akan ada perbedaan dengan kondisi sebenarnya ketika tahun pajak sekarang sudah berakhir. Selisih tersebutlah yang kita bayar sebagai kekurangan pajak akhir tahun. Kekurangan bayar akhir tahun ini biasa dinamakan $\mathrm{PPh}$ Pasal 29. Apabila selisihnya menunjukkan lebih bayar, maka kondisi ini dinamakan restitusi atau Wajib Pajak meminta kelebihan pembayaran pajak yang telah dilakukan.Pada umumnya angsuran pajak ini adalah sebesar Pajak Penghasilan terutang menurut SPT Tahunan Pajak Penghasilan tahun lalu dikuranggi dengan kredit pajak Pajak Penghasilan Pasal 21, 22, 23 dan Pasal 24, dibagi 12 atau banyaknya bulan dalam bagian tahun pajak. Misal, SPT Tahunan 2011 menunjukkan data sebagai berikut :
Pajak Penghasilan terutang
50.000 .000
Kredit Pajak PPh Pasal 21,22,23 dan 24
35.000 .000

Maka, PPh Pasal 25 tahun 201X yang harus dibayar tiap bulan adalah sebagai berikut.

Pajak Penghasilan terutang

50.000 .000

Kredit Pajak PPh Pasal 21,22,23 dan 24

35.000 .000

Selisih

15.000 .000

PPh Pasal $25=$ selisih : $12=$

1.250 .000

\section{Pelaporan PPh Pasal 25}

Pembayaran PPh Pasal 25 harus dilakukan paling lambat tanggal 15 bulan berikutnya, dan pelaporannya paling lambat tanggal 20 bulan berikutnya setelah masa pajak berakhir.Menurut Peraturan Dirjen Pajak No.PER-22/PJ/2008 bahwa pembayaran PPh Pasal 25 melalui modul penerimaan negara (MPN) dan SSP PPh Pasal 25 yang telah mendapat validasi NTPN (nomor transaksi penerimaan Negara) dari bank, maka Wajib Pajak dianggap telah melakukan pelaporan PPh Pasal 25.

\section{Perhitungan Pajak Terutang}

Dalam menghitung Pajak Penghasilan yang terutang, dibedakan antara Wajib Pajak dalam negeri dan Wajib Pajak luar negeri. Bagi Wajib Pajak Badan dalam negeri pada dasarnya untuk menentukan besarnya Penghasilan Kena Pajak yaitu perhitungan Pajak Penghasilan dengan dasar pembukuan.Sementara Wajib Pajak Orang Pribadi yang peredaran brotonya di bawah Rp. 600.000.000,00(enam ratus juta) diperkenankan menggunakan norma perhitungan penghasilan neto

berdasarkan pencatatan. Orang pribadi yang berada di Indonesia untuk jangka waktu secara berturut-turut yang lebih dari 183 (seratus delapan puluh tiga) hari dianggap sebagai Wajib Pajak dalam negeri, dan wajib memenuhi kewajiban dan haknya selaku Wajib Pajak dalam negeri. Wajib Pajak yang meninggalkan Indonesia untuk jangka waktu yang tidak lebih dari 1 (satu) tahun, masih merupakan Wajib Pajak dalam negeri dan masih dikenakan pajak di Indonesia. 


\section{Penelitian Terdahulu}

Separingga (2014) meneliti tentang Analisis Penerapan Tax Planning Dalam MeminimalkanPembayaran Pajak Penghasilan Badan PadaPT Pupuk Sriwidjaja Palembang. Metode penelitian yang digunakan adalah metode kualitatif.Hasil penelitian menunjukan penerapan perencanaan pajak pada PT. Pupuk Sriwidjaja Palembang telah berjalan sesuai dengan Undang - Undang PPh No. 36 tahun 2008 sehingga tidak melanggar ketentuan yang berlaku dengan terjadi efisiensi pembayaran beban pajak penghasilan.

Renita (2013) meneliti tentang Penerapan Perencanaan Pajak Penghasilan Badan Sebagai upaya EfesiensiPembayaran Pajak PT SINAR SASONGKO.Metode penelitian yang digunakan adalah penelitian deskriptif kualitatif dan hasil penelitian menunjukan PT. Sinar Sasongko merupakan perusahaan yang juga melakukan pembukuan untuk menyediakan informasi yang menyangkut laporan keuangan perusahaan agar dapat dinilai kinerjanya.

\section{METODE PENELITIAN}

\section{Jenis Penelitian}

Jenis penelitian yang digunakan penulis adalah penelitian deskriptif, yang dilakukan dengan cara mengumpulkan data yang berhubungan dengan permasalahan yang dihadapi. Data merupakan keterangan-keterangan yang diperoleh dari penelitian atau melalui referensireferensi untuk mengetahui Penerapan Perencanaan Pajak atas Pajak PPh pasal 25 pada PT. Bank SulutGo.

\section{Tempat dan Waktu Penelitian}

Penelitian ini dilaksanakan pada PT. Bank SulutGo. Penelitian ini berlangsung pada bulan Juni s/d selesai 2017.

\section{Metode Pengumpulan Data}

Metode yang digunakan dalam pengumpulan data meliputi:

1. Observasi (pengamatan)

Nasution (1988) dalam Sugiyono (2012 :64) Menyatakan bahwa observasi adalah dasar semua ilmu pengetahuan. Para ilmuwan hanya dapat bekerja berdasarkan data, yaitu fakta mengenai dunia kenyataan yang diperoleh melalui observasi. Metode ini digunakan dengan maksud untuk mengamati dan mencatat gejala-gejala yang tampak pada objek penelitian pada saat keadaan atau situasi yang alami atau yang sebenarnya sedang berlangsung, meliputi kondisi sumber daya manusia, komitmen dari pimpinan

2. Interview (Wawancara)

Moleong (2011:186) Mengatakan bahwa wawancara adalah percakapan dengan maksud tertentu.Percakapan itu dilakukan oleh dua pihak, yaitu pewawancara (interviewer) yang mengajukan pertanyaan dan terwawancara (interview) yang memberikan jawaban atas pertanyaan itu. Metode ini dilakukan dengan cara mewawancarai secara langsung dan mendalam (indepth interview) kepada pihak yang terlibat dan terkait langsung guna mendapatkan penjelasan pada kondisi dan situasi yang sebenarnya pula.

3. Dokumentasi

Sugiyono (2012:82) menyatakan bahwa dokumen merupakan catatan peristiwa yang sudah berlalu. Dokumen bisa berbentuk tulisan, gambar, atau karya-karya monumental dari seseorang.

\section{Metode Analisis}

Metode analisis data yang digunakan dalam penelitian ini adalah metode deskriptif, yaitu membahas masalah dengan cara mengumpulkan, menguraikan, menghitung, dan membandingkan suatu keadaan serta menjelaskan suatu keadaan sehingga dapat ditarik 
kesimpulan yang meliputi Penerapan Perencanaan Pajak atas Pajak PPh pasal 25 pada PT. Bank SulutGo

\section{HASIL PENELITIAN DAN PEMBAHASAN}

\subsection{Perhitungan Pajak Penghasilan Sebelum Perencanaan Pajak \\ Laporan Laba/Rugi Fiskal}

Berikut disajikan laporan laba/rugi tahun 2016 beserta dengan perhitungan pajak penghasilan tahun 2016 yang harus dibayar oleh perusahaan.

Tabel 4.2 Laporan Laba Rugi (sebelum Perencanaan Pajak)

PT. Bank SulutGo

per 31 Desember 2016 (dalam Rupiah)

\begin{tabular}{|c|c|c|c|}
\hline & Komersial & Koreksi & Fiskal \\
\hline \multicolumn{4}{|l|}{$\begin{array}{l}\text { PENDAPATAN } \\
\text { BUNGA }\end{array}$} \\
\hline $\begin{array}{c}\text { Kredit yang } \\
\text { diberikan }\end{array}$ & 1.630 .194 .809 .738 & & 1.630 .194 .809 .738 \\
\hline \multirow{2}{*}{$\begin{array}{l}\text { Penempatan pada } \\
\text { Bank Indonesia } \\
\text { Bunga surat } \\
\text { berharga }\end{array}$} & 36.263 .278 .081 & & 36.263.278.081 \\
\hline & 57.003.978.221 & & 57.003.978.221 \\
\hline \multirow{2}{*}{$\begin{array}{l}\text { Penempatan pada } \\
\text { Bank lain } \\
\text { Pendapatan bunga } \\
\text { lainnya }\end{array}$} & 24.107.106.791 & & 24.107.106.791 \\
\hline & 1.148 .016 .953 .607 & & 1.148 .016 .953 .607 \\
\hline \multirow{2}{*}{$\begin{array}{c}\text { Jumlah Pendapatan } \\
\text { Bunga } \\
\text { BEBAN BUNGA }\end{array}$} & 2.895.586.126.438 & & 2.895.586.126.438 \\
\hline & & & \\
\hline $\begin{array}{l}\text { Deposito } \\
\text { Surat herharoa }\end{array}$ & 581.310 .694 .412 & & 581.310 .694 .412 \\
\hline $\begin{array}{l}\text { Surat bernarga } \\
\text { (Obligasi yang } \\
\text { diterbitkan) }\end{array}$ & 89.250 .000 .004 & & 89.250 .000 .004 \\
\hline Tabungan & 31.196 .566 .433 & & 31.196 .566 .433 \\
\hline \multirow{2}{*}{$\begin{array}{c}\text { Giro } \\
\text { Bank lain }\end{array}$} & 57.254 .223 .079 & & 57.254 .223 .079 \\
\hline & 5.731 .142 .691 & & 5.731 .142 .691 \\
\hline $\begin{array}{c}\text { Pinjaman yang } \\
\text { diterima }\end{array}$ & 1.124 .943 .802 .190 & & 1.124 .943 .802 .190 \\
\hline Beban bunga lainnya & - & & - \\
\hline \multirow{3}{*}{$\begin{array}{c}\text { Jumlah Beban } \\
\text { Bunga } \\
\text { Jumlah Pendapatan } \\
\text { Bunga - Beban } \\
\text { Bunga } \\
\text { Pendapatan } \\
\text { Operasi Lainnya }\end{array}$} & 1.889.686.428.809 & & 1.889.686.428.809 \\
\hline & 1.005.899.697.629 & & 1.005.899.697.629 \\
\hline & & & \\
\hline \multirow{2}{*}{$\begin{array}{l}\text { Provisi dan Komisi } \\
\text { lainnya } \\
\text { Pendapatan }\end{array}$} & 21.156 .539 .670 & 3.450 .652 .019 & \\
\hline & 39.747.985.266 & & \\
\hline
\end{tabular}




\begin{tabular}{|c|c|c|c|}
\hline & Komersial & Koreksi & Fiskal \\
\hline \multicolumn{4}{|l|}{ Administrasi } \\
\hline Pendapatan Denda & 13.077 .694 .992 & 6.151 .350 .000 & \\
\hline $\begin{array}{lr}\text { Keuntungan } & \text { dari } \\
\text { Perubahan } & \text { Nilai } \\
\text { Wajar } & \text { Aset } \\
\text { Keuangan } & \\
\end{array}$ & 220.536 .779 .920 & 17.008 .551 .885 & \\
\hline Pendapatan Lainnya & 267.758 .456 & 30.504 .161 .425 & \\
\hline \multirow{3}{*}{$\begin{array}{c}\text { Jumlah Pendapatan } \\
\text { Operasi Lainnya } \\
\text { PENYISIHAN } \\
\text { KERUGIAN ASET } \\
\text { Kredit yang } \\
\text { diberikan }\end{array}$} & 294.786.758.304 & & 294.786.758.304 \\
\hline & & & \\
\hline & 16.519 .801 .885 & & 16.519 .801 .885 \\
\hline \multirow{2}{*}{$\begin{array}{c}\text { Penyertaan saham } \\
\text { BPR Prisma Dana I } \\
\text { Penempatan pada } \\
\text { Bank lain }\end{array}$} & 488.750 .000 & & 488.750 .000 \\
\hline & & & \\
\hline \multicolumn{4}{|l|}{ Dikurangi : } \\
\hline \multicolumn{4}{|l|}{$\begin{array}{c}\text { Pendapatan Koreksi } \\
\text { CKPN }\end{array}$} \\
\hline \multirow{5}{*}{$\begin{array}{c}\text { Kredit yang } \\
\text { diberikan } \\
\text { Penempatan pada } \\
\text { Bank lain } \\
\text { Jumlah Penyisihan } \\
\text { Kerugian Aset } \\
\text { Produktif dan Aset } \\
\text { Non Produktif } \\
\text { Beban Operasional } \\
\text { Lainnya } \\
\text { Beban Personalia : }\end{array}$} & (8.554.314.879) & $(15.383 .184 .833)$ & \\
\hline & & & \\
\hline & (8.454.237.000) & & (8.454.237.000) \\
\hline & & & \\
\hline & & & \\
\hline Gaji dan upah & 134.770 .177 .035 & 3.450 .652 .019 & \\
\hline Tunjangan & 323.284 .532 .355 & 2.583 .561 .622 & \\
\hline \multirow{2}{*}{$\begin{array}{l}\text { Honorarium } \\
\text { Pendidikan dan } \\
\text { latihan }\end{array}$} & 7.641 .279 .388 & & \\
\hline & 37.697 .039 .029 & 768.497 .050 & \\
\hline \multirow{2}{*}{$\begin{array}{c}\text { Imbalan pasca kerja } \\
\text { Jumlah }\end{array}$} & 12.201 .638 .300 & 12.201 .638 .300 & \\
\hline & (515.594.666.107) & & (515.594.666.107) \\
\hline \multicolumn{4}{|l|}{$\begin{array}{l}\text { Beban Administrasi } \\
\text { dan Umum : }\end{array}$} \\
\hline \multirow{3}{*}{$\begin{array}{c}\text { Sewa } \\
\text { Profesional } \\
\text { Asuransi }\end{array}$} & 39.431 .806 .507 & 4.979 .083 .000 & \\
\hline & 8.165 .118 .155 & & 8.165 .118 .155 \\
\hline & 10.488 .099 .194 & 101.812 .884 & \\
\hline $\begin{array}{l}\text { Pajak kendaraan, } \\
\text { bumi bangunan dan }\end{array}$ & 11.861 .172 .155 & 11.461 .086 .793 & \\
\hline
\end{tabular}




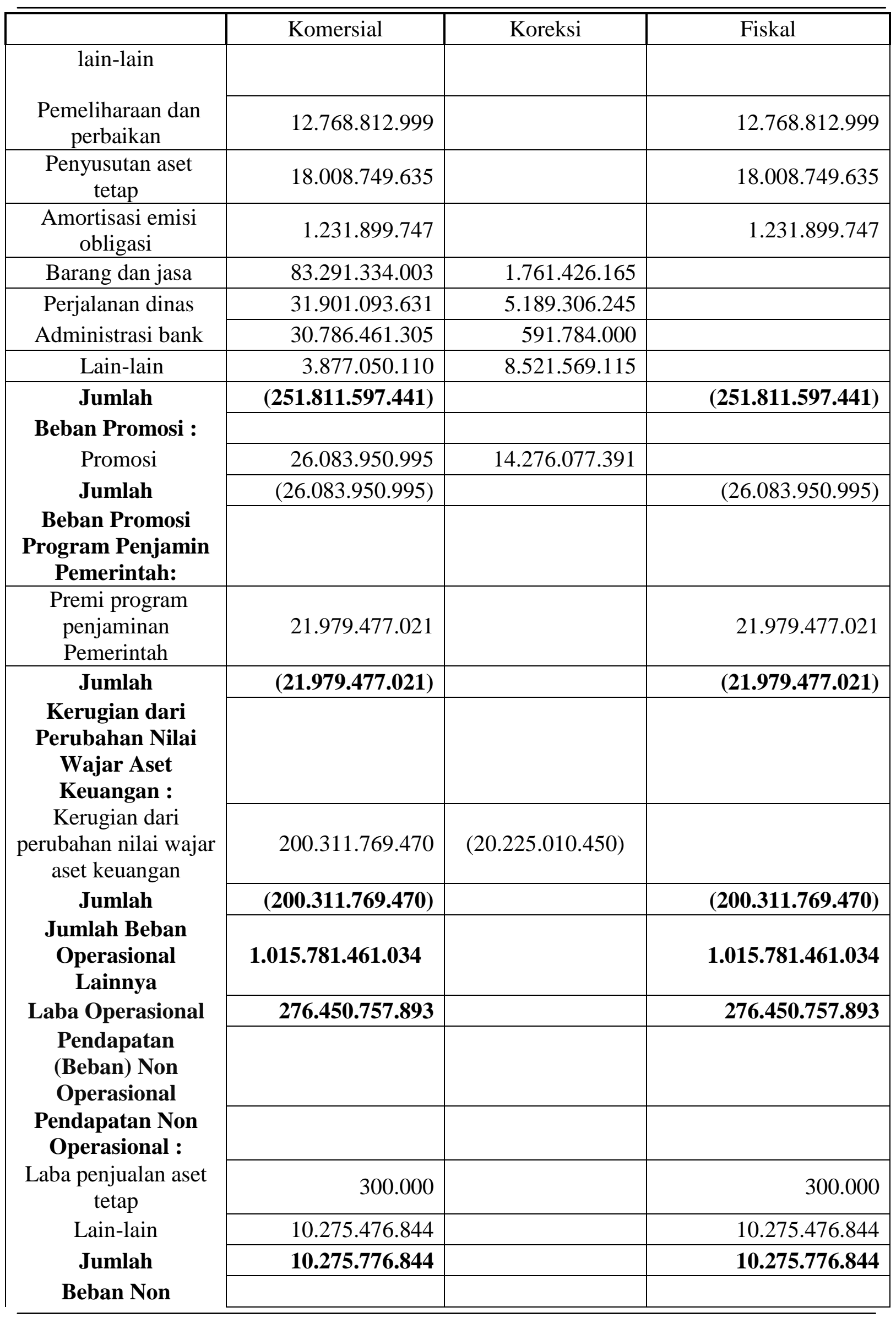




\begin{tabular}{|c|r|r|r|}
\hline & Komersial & Koreksi & \multicolumn{1}{|c|}{ Fiskal } \\
\hline Operasional : & & & \\
Denda & $(209.614 .633)$ & & \\
\cline { 2 - 4 } $\begin{array}{c}\text { Corporate Social } \\
\text { Resposibility }(C S R) \\
\text { Lain-lain }\end{array}$ & - & 593.233 .000 & \\
\cline { 2 - 4 } $\begin{array}{c}\text { Jumlah Beban Non } \\
\text { Operasional }- \\
\text { Bersih }\end{array}$ & $(28.898 .356 .072)$ & 9.698 .396 .628 & $\mathbf{( 1 8 . 8 3 2 . 1 9 3 . 8 6 1 )}$ \\
\cline { 2 - 4 } $\begin{array}{c}\text { Laba Sebelum } \\
\text { Pajak Penghasilan }\end{array}$ & $\mathbf{( 1 8 . 8 3 2 . 1 9 3 . 8 6 1 )}$ & & $\mathbf{1 1 . 2 1 9 . 9 0 0 . 4 4 1 . 9 5 6}$ \\
\cline { 2 - 4 } & $\mathbf{2 5 7 . 6 1 8 . 5 6 4 . 0 3 2}$ & & $\mathbf{1 1 . 2 1 9 . 9 0 0 . 4 4 1 . 9 5 6}$ \\
\hline $\begin{array}{c}\text { Laba Bersih Tahun } \\
\text { Berjalan }\end{array}$ & $\mathbf{1 7 3 . 4 1 8 . 0 7 9 . 3 6 1}$ & & \\
\hline
\end{tabular}

Sumber : Data Olahan, 2017

Berdasarkan Laporan Laba Rugi di atas, diperoleh laba perusahaan sebelum penerapan Perencanaan Pajak adalah sebagai berikut.

$25 \%$ x 257.618.564.000 64.404 .641 .000

Angsuran PPh Pasal 25 tahun 2016 adalah :

64.404.641.000: $12=$

5.367.053.417 per bulan

\subsubsection{Perhitungan Pajak Penghasilan Sesudah Perencanaan Pajak}

\subsubsection{Rekonsiliasi Fiskal}

Rekonsiliasi antara laba (rugi) sebelum manfaat (beban) pajak seperti yang disajikan dalam laporan laba rugi komprehensif untuk periode yang berakhir pada tanggal 31 Desember 2016 oleh PT. Bank SulutGosebagai berikut.

Tabel 4.3 Laporan Laba Rugi (sesudah perencanaan pajak)

PT. Bank SulutGo

per 31 Desember 2016 (dalam Rupiah)

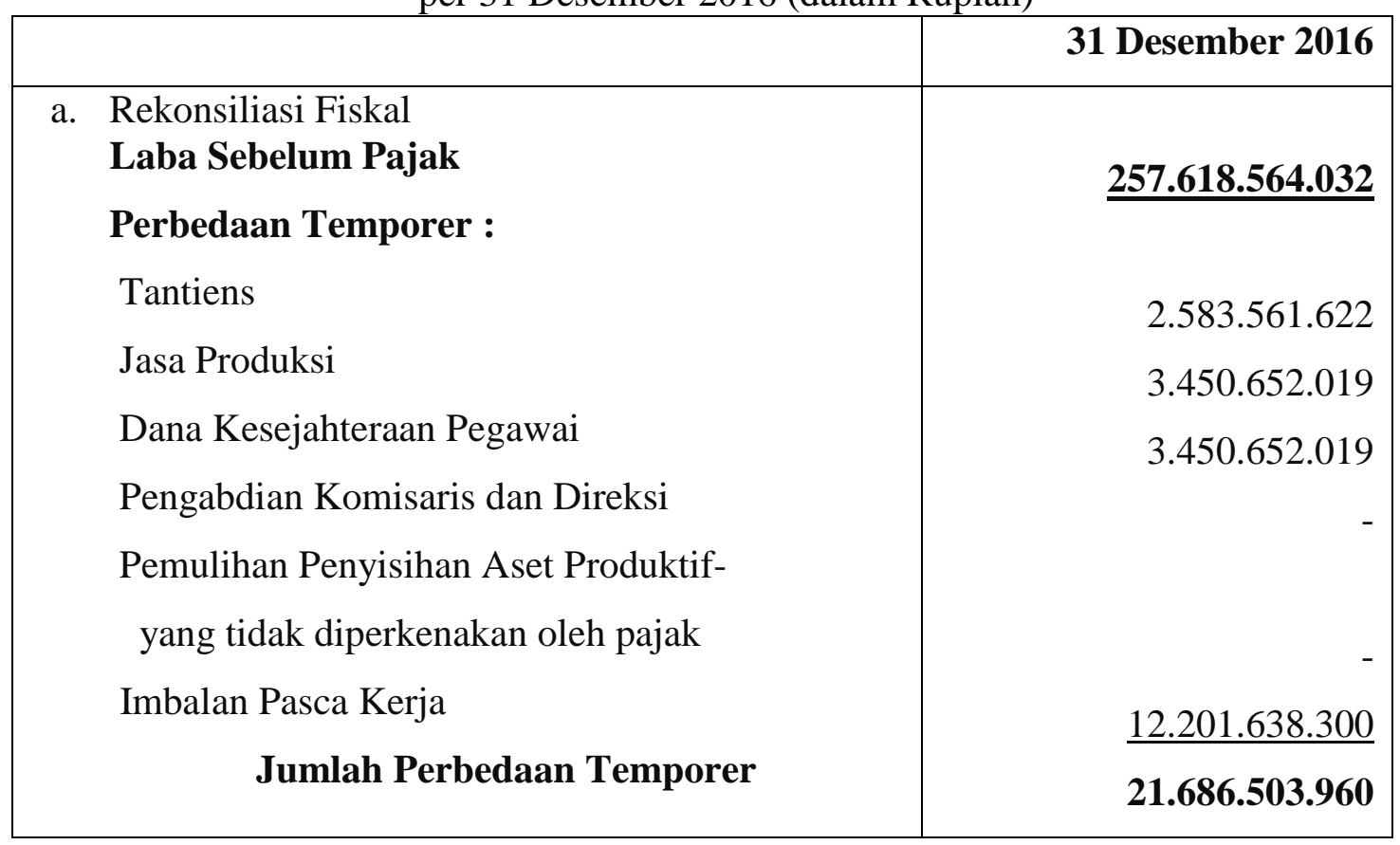




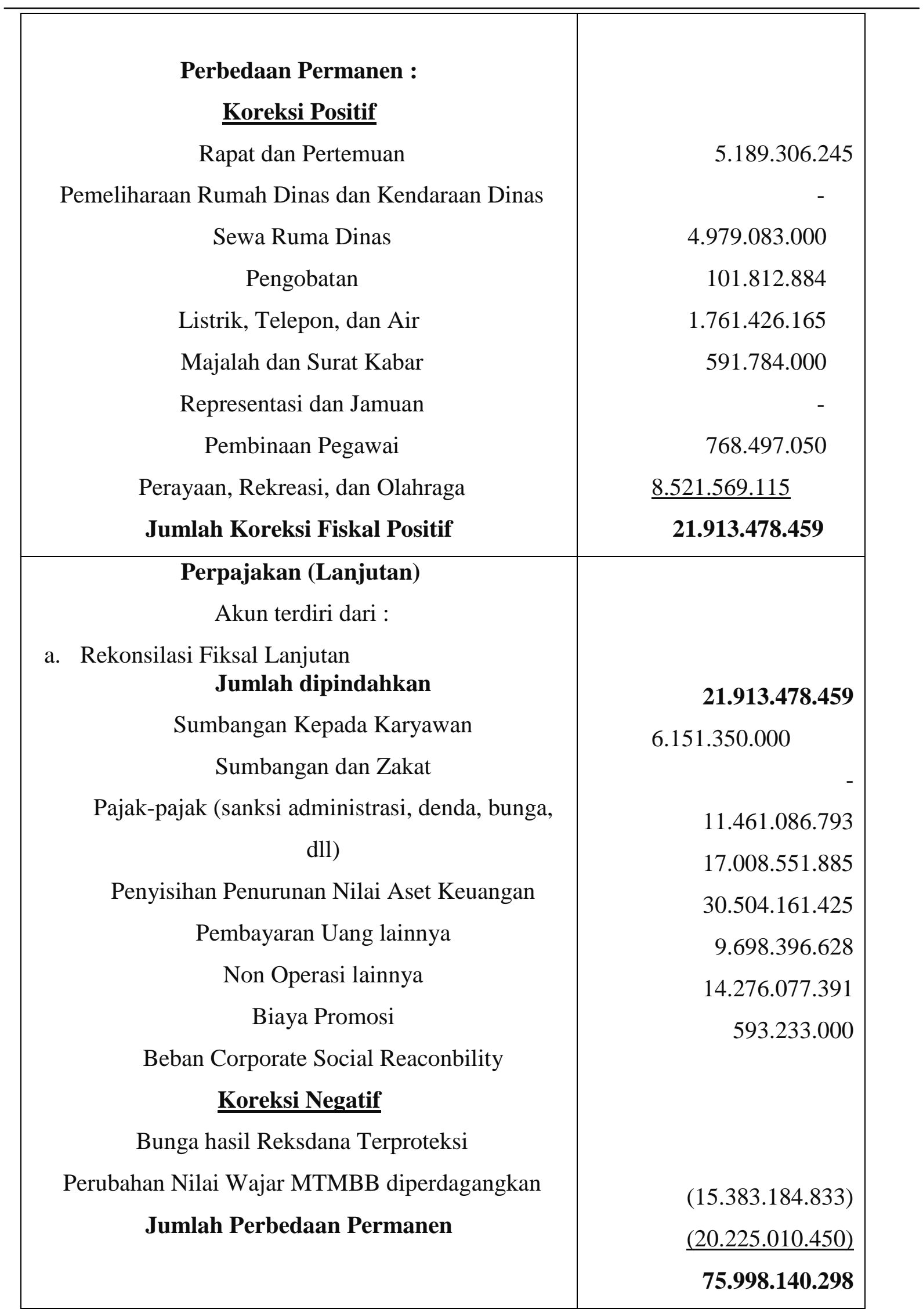


Berdasarkan Laporan Laba Rugi di atas, diperoleh laba perusahaan sebelum penerapan Perencanaan Pajakadalah sebagai berikut.

$25 \%$ x 355.303.208.000

88.825 .802 .000

Angsuran PPh Pasal 25 tahun 2016 adalah :

88.825.802.000: $12=$

7.402.150.167 per bulan

\subsubsection{Pajak Penghasilan Menurut PT. Bank SulutGo}

Tabel 4.4 Pajak Penghasilan Menurut PT. Bank SulutGo

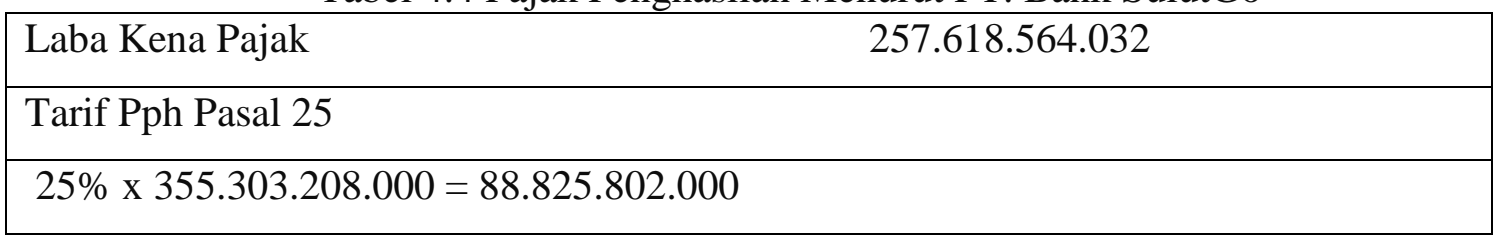

Sumber : Internal Perusahaan

\subsubsection{Perhitungan Pph Pasal 25 PT. Bank SulutGo}

Tabel 4.5 Perhitungan Pph Pasal 25 PT. Bank SulutGo

\begin{tabular}{|l|r|r|}
\hline Perhitungan Pph Pasal 25 & 88.825 .802 .000 \\
\hline Pph menurut SPT tahun lalu & $\underline{6.562 .366 .507}$ & \\
\hline Pengurangan Kredit Pajak & $\underline{6.562 .366 .507}$ \\
\hline Pph Pasal 29 & 82.263 .436 .493 \\
\hline \multicolumn{2}{|c|}{ Total Kredit Pajak } & \\
\hline \multicolumn{2}{|c|}{ Dasar Perhitungan Angsuran } & 8 \\
\hline
\end{tabular}

Sumber : Internal Perusahaan, 2017

\subsection{Pembahasan}

Berdasarkan hasil perbandingan antara laba sebelum dan sesudah pelaksanaan Perencanaan Pajak, terlihat bahwa laba sesudah pelaksanaan Perencanaan Pajaklebih besar dari laba sebelum pelaksanaan Perencanaan Pajak. Hal ini menunjukkan bahwa perusahaan telah melakukan peminimalan pajak. Dengan demikian Penerapan Pajak dapat dijadikan alternatif untuk meminimalkan beban pajak terutang badan.

Dari perhitungan sebelum penerapan pajak, pajak penghasilan terutang yang harus dibayarkan oleh PT. Bank SulutGo adalah sebesar Rp 88.825.802.000. Dari laporan laba/rugi yang telah disajikan dapat dilakukan oleh perusahaan untuk mengefisienkan pajak terutang yaitu, dengan menggunakan perencanaan pajak dengan $\mathrm{PPh}$ pasal 25 sebagaimana $\mathrm{PPh}$ pasal 25 dapat memberikan kemudahan pembayaran pajak dengan cara diangsur.

Pengurangan pembayaran pajak terjadi setelah menggunakan PPh pasal 25 dimana 25\% dikalikan dengan laba fiskal $\mathrm{Rp}$ 355.303.208.000, maka mendapatkan hasil $\mathrm{Rp}$ 88.825.802.000. Dan untuk mendapatkan PPh pasal 25, hasil dari laba setelah fiskal dikurangi PPh pasal 29 sebesar Rp 6.562.365.507. Maka Pengehematan pajak PPh pasal 25 akibat dilakukannya perencanaan pajak adalah sebesar Rp 82.263.436.493 Dengan adanya Perencanaan Pajak, menyebabkan komponen penghasilan kena pajak turun, sehingga pajak terutang perusahaan juga turun. Dengan demikian perusahaan memiliki dana lebih yang dapat ditanamkan kembali untuk pengembangan perusahaan lebih lanjut. Hasil penelitian di atas sejalan dengan konsep tentang Perencanaan Pajak. Dalam konteks ini Perencanaan Pajakmerupakan penghindaran pajak legal yang dapat ditempuh oleh wajib pajak untuk efisiensi beban pajak. Dasar pemikiran dari perencanaan pajak tersebut adalah usaha 
pengaturan seluruh aktifitas perusahaan guna menghindari konsekuensi perpajakan seminimal mungkin.

Tabel 4.7 Perbandingan Penerapan Perrencanaan Pajak PPh Badan Menurut PT. Bank SulutGo

\begin{tabular}{|c|c|}
\hline $\begin{array}{c}\text { Penerapan Perencanaan Pajak Menurut } \\
\text { PT. Bank SulutGo }\end{array}$ & $\begin{array}{c}\text { Penerapan Perencanaan Pajak Menurut } \\
\text { Ketentuan Perpajakan }\end{array}$ \\
\hline $\begin{array}{l}\text { Perhitungan } \mathrm{PPh} \text { terutang pada PT. Bank } \\
\text { SulutGo dikenakan sebesar Rp } \\
\text { 6.562.365.507 dan angsura pajak sebesar } \\
\mathrm{Rp} \quad 82.263 .436 .493 \text { Perhitungan } \mathrm{PPh} \\
\text { terutang tersebut menggunakan tarif 25\% } \\
\text { dari penghasilan kena pajak. }\end{array}$ & $\begin{array}{l}\text { Perhitungan PPh terutang pada PT. Bank } \\
\text { SulutGomenurut Perhitungan PPh } \\
\text { terutang tersebut menggunakan tarif } \\
25 \% \text { dari penghasilan kena pajak dengan } \\
\text { mengikuti aturan perpajakan terbaru } \\
\text { seperti yang tercantum pada peraturan } \\
\text { perpajakan. }\end{array}$ \\
\hline
\end{tabular}

Sumber : Internal Perusahaan, 2017

Dari tabel diatas bisa dilahat bahwa Perbandingan Penerapan Perrencanaan Pajak PPh Badan Menurut PT. Bank SulutGo telah sesuai dengan Ketentuan Perpajakan

\section{KESIMPULAN DAN SARAN Kesimpulan}

Penerapan perencanaan pajak yang dilakukan oleh PT. Bank SulutGo untuk meminimalkan jumlah pajak penghasilan terutang menghasilkan beberapa kesimpulan sebagai berikut :

1. PT. Bank Sulut dalam menjalankan aktivitasnya belum sepenuhnya melakukan perencanaan pajak. Laporan Laba/Rugi untuk periode yang berakhir pada tahun 2016. Adapun besarnya Pajak Penghasilan PT. Bank SulutGo pada periode tersebut adalah Rp. 88.825.802.000

2. Setelah melakukan penghitungan atas Laba Laba/Rugi (LKP) PT. Bank SulutGo dengan menggunakan Perencanaan Pajak maka besarnya Pajak Penghasilan untuk periode yang berakhir tahun 2016 adalah sebesar Rp. 82.263.436.493

3. Terdapat selisih Pajak Penghasilan yang dihemat setelah dilakukan penghitungan dengan menggunakan Perencanaan Pajak untuk perode yang berakhir pada tahun 2016 yaitu sebesar Rp. 6.562.365.507

4. Dalam menerapkan strategi pelaksanaan pajak, perusahaan memiliki beberapa kebijakan-kebijakan akuntansi yang dijadikan acuan. Selain itu, perusahaan juga melakukan beberapa langkah seperti, memaksimalkan penghasilan yang dikecualikan melalui pemaksimalan penghasilan bunga, memaksimalkan biaya fiskal dan meminimalkan biaya yang tidak diperkenankan sebagai pengurang. 


\section{Saran}

Berdasarkan hasil penelitian dan pembahasan di atas, maka penulis memberi saran sebagai berikut :

1. Bagian perpajakan PT. Bank SulutGo sebaiknya selalu mengikuti perkembangan aturanaturan pajak yang berlaku agar dalam melakukan penerapan perencanaan pajak, tidak bertentangan dengan aturan-aturan tersebut.

2. Dengan perencanaan pajak yang telah berjalan efisien diharapkan perusahaan dapat dengan konsisten melaksanakan perencanaan pajak secara terus menerus

\section{DAFTAR PUSTAKA}

Peraturan Menteri Keuangan RI Nomor 02/PMK.03/2010 Tentang Biaya Promosi yang Dapat Dikurangkan Dari Penghasilan Bruto

Republik Indonesia.2008.Undang-undang nomor 36 tahun 2008 Tetntang Perubahan keempat Atas Undang-Undang Nomor 7 Tahun 1983 Tentang Pajak Penghasilan

Rumuy, Renita, \& Rizal Effendi, 2013. Penerapan Perencanaan Pajak Penghasilan Badan sebagai Upaya Efisiensi Pembayaran Pajak PT Sinar Sasongko

Surat Edaran Dirjen Pajak Nomor S-302/PJ.42/2002 Tentang Perlakuan PPh Atas Biaya Pemakaian Telepon Seluler dan Kendaraan Perusahaan.

Surat Edaran Dirjen Pajak Nomor SE-27/PJ.22/1986 Tentang Biaya Entertainment dan Sejenisnya.

Surat Edaran Dirjen Pajak Nomor SE-14/PJ/2003 Tentang Biaya Penyedian Makanan dan Minuman Oleh Pemberi Kerja Bagi Seluruh Pegawai Di Tempat Kerja.

Surat Edaran Dirjen Pajak Nomor SE-14/PJ/2003 Tentang Biaya Perlakuan Biaya Bunga yang Dibayar atau Terutang Dalam Hal Wajib Pajak Memperoleh Penghasilan berupa Bunga Deposito atau Tabungan Lainnya.

Waluyo.Perpajakan Indonesia . Edisi Revisi. Jakarta : Penerbit Salemba Empat. 2008 